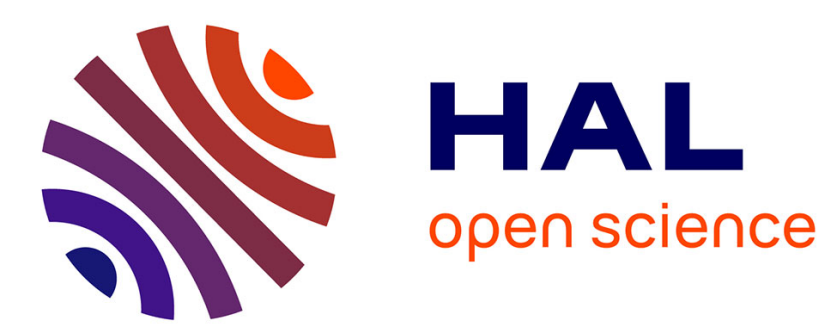

\title{
Freudian modalities of disbelief
}

Nicolas Guérin, Marie Lenormand, Jean-Jacques Rassial

\section{To cite this version:}

Nicolas Guérin, Marie Lenormand, Jean-Jacques Rassial. Freudian modalities of disbelief. International Journal of Psychoanalysis, 2014, 95 (5), pp.819-841. 10.1111/1745-8315.12181 . hal-01327577

\section{HAL Id: hal-01327577 https://hal-amu.archives-ouvertes.fr/hal-01327577}

Submitted on 17 Jun 2016

HAL is a multi-disciplinary open access archive for the deposit and dissemination of scientific research documents, whether they are published or not. The documents may come from teaching and research institutions in France or abroad, or from public or private research centers.
L'archive ouverte pluridisciplinaire HAL, est destinée au dépôt et à la diffusion de documents scientifiques de niveau recherche, publiés ou non, émanant des établissements d'enseignement et de recherche français ou étrangers, des laboratoires publics ou privés. 


\section{Freudian modalities of disbelief}

Nicolas Guérin, Marie Lenormand, Jean-Jacques Rassial

Aix Marseille Université, LPCLS EA 3278, 13331, Marseille, France

This article can be characterised as a 'rediscovery of a notion of psychoanalysis that had disappeared or had been confused by later operations. The authors explorea Freudian notion that has been unjustly misunderstood, especially because of the multiple ways in which 'Unglaube'disbelief - has been translated. We shall establish the archaeology of this term in Freud by extracting its three significant modes. First, paranoic disbelief designates an unconscious process of the rejection of belief in the subject's first encounter with a sexual reality that is always traumatic. Secondly, the obsessional neurotic's disbelief, which we shall call 'incredulity', is a secondary, less radical refusal of belief, one that is different from its paranoic counterpart. Finally, we shall envision a third - dialectical - type of disbelief, which Freud called 'act of disbelief' and which will enable us to approach the fundamental epistemic and ethical stakes for psychoanalysis.

Keywords : disbelief, incredulity, paranoia, obsessional neurosis, psychoanalytic treatment, ethics

\section{Towards an Archaeology of Unglaube}

During a lecture given on 22 February 1969 at the Collège de France, which was entitled 'What Is an Author', the French philosopher Michel Foucault ${ }^{1}$ hypothesised that the nineteenth century witnessed the appearance, in History of Systems of Thought chair at the Collège de France. A critic of norms and of the principles of power, especially in repressive institutions (mental institutions and prisons), his work as a whole is based on what he defined in a book of the same title as an 'archeology of knowledge.' He was the author of many notable books, articles and presentations such as The History of Madness in the Classical Age (1964), The Order of Things [Les Mots et les Choses] (1966), The History of Sexuality (1976 - 1984), etc. 
Europe, of particular types of authors, who are to be distinguished from literary authors and the founders of sciences.

These 'initiators of discursive practice', represented principally by Freud, 'produced not only their own work, but the possibility and the rules of formation of other texts' (1977 [1969], p.131).

For example, Freud produced a body of work that has enabled other authors to produce new texts containing new theories, which nevertheless refer to his initial ideas. Together, these texts form a field (what Foucault calls a 'discursive practice') that can be designated by the term, 'Freudianism.'

The fields that were thus established, which include principally psychoanalysis, imply certain particular requirements in their approach: what Foucault calls a 'return to', which should be distinguished from a 'rediscovery' and a 'reactivation'.

'Rediscovery' (redécouverte) involves understanding how the current form of knowledge can make us perceive a figure that was confused or had disappeared in an older form.

By 'reactivation' (réactualisation), Foucault means the reinsertion of a notion into a new field of application, that is, into a domain or context that is different from that in which the notion had its origin.

Finally, the 'return to' designates a movement that does not exclude the two preceding ones, but is distinguished from them by having its proper specificity': it applies to fieldsfwhat is called the 'initiation of a discursive practice') that do no belong to the sciences. Its characteristic is to return 'to 
a text in itself, specifically, to a primary and unadorned text', to the author's founding act. In particular, Foucault citesthe example of the 'return to Freud' effected by... we are tempted to add, Jacques Lacan. Lacan attended Foucault's lecture at the Collège de France; Foucault however did not acknowledge his presence, despite having borrowed both the expression 'return to' and its meaning from his work. ${ }^{2}$

Our hypothesis is that Lacan's 'return to' Freud permits us to rediscover, in Foucault's sense, a variety of Freudian concepts; in this paper, we will take up the concept of Unglaube, ${ }^{3}$ which can be translated initially by 'disbelief'. This notion has had some erratic vicissitudes in Freud's work. 'Unglaube' has sometimes been used in an ordinary and metapsychologically insignificant sense, just as it has also been 'covered over' by other notions and its very existence has been obscured by the various ways that it has been translated. For these reasons, it has disappeared or has been 'diluted' in the multiple readings and interpretations of Freud's work, despite its presence in this work. (Lacan, 2002 [1946], p.133), Lacan, as of 1953, characterised his approach as a 'return to Freud' (Lacan, 2002 [1953], p.249).

It is useful to specify that, like the term 'Name', the word 'Unglaube' is inflected with $-(e) n$ unless is it in the nominative, and is inflected with -(e)ns in the genitive; therefore the forms, 'Unglauben' and 'Unglaubens', which we can find in the original text, do not constitute another word. For this reason, the term appears in the Grimm Brothers' German dictionary (1961) with the inflection in parentheses: Unglaube(n). In what follows, we shall use this word in the nominative: Unglaube. 
We would like to make it clear that the goal of this article is not a Lacanian reactivation of the notion of disbelief, a project that would deserve a separate article. Its aim is to undertake an archaeology of this notion in Freud's work, and this study will be centred exclusively on Freud's most important uses of this term. When Lacan exhumes the concept of disbelief in 1959-60 (Lacan, 1992 [1959-60], p.54 and p.130) and then here and there in his seminar (Lacan, 1981 [1964], p.238; (1964-65) 19th May 1965 Session; 2007 [1969-70], p.63), he speaks about it succinctly and even allusively, sticking to its psychotic modality, without commenting extensively on Freud's text even while extending the notion's meaning by importing it into his own conceptualisation. For our part, we shall offer a detailed and crossreferenced reading of Freud's texts in order to emphasise the coherence of his elaboration of disbelief and to argue for its metapsychological consistency.

Our project is, on the one hand, to bring out the theoretical and clinical value of such a notion and, on the other, to make it known to an Englishspeaking public, to whom it remains unfairly unknown. This notion has given rise only to several works by Lacanian psychoanalysts, mainly in France. Yet up to the present day, none of these articles has centred on an exclusive study of the vicissitudes of this notion in Freud. We shall note, in addition, that there are only a few of these articles and that their quality is uneven. Often short, they were published in French journals and do not consist exclusively in a rediscovery of the notion through a reading that delves thoroughly into Freud's texts. Although most of these articles restrict 
themselves to the paranoic modality of disbelief, some of them refer to Freud's use of the notion, but miss most of its occurrences (Turnheim, 1992), others offer a very brief clarification of its Lacanian meaning (Hellebois, 1992), while others explore the gap between Freud's and Lacan's uses of this term (Guérin, 2006) or give a new application to its psychotic modality (Porge, 1996).

The goal of our work of rediscovery of Freud's notion of disbelief, a work that will proceed by means of an attentive examination of Freud's texts, is to emphasise the extent to which this concept structures, for the father of psychoanalysis, a theorisation of paranoia and obsessional neurosis and, in addition, enables us to see from a new angle what founds the analyst's theory and practice.

In this article, we shall therefore assess three clinical modalities of Unglaube which are more or less scattered throughout Freud's work: paranoic disbelief, the obsessional neurotic's incredulity and finally, a particular form of disbelief, to which Freud gave a personal testimony, and which makes it possible to theorise the orientation and work of psychoanalytic treatment itself.

\section{Glaube and Unglaube}

This word Unglaube is constructed by using the negative prefix, 'un-' and 'Glaube', belief, and refers etymologically to a 'negation' of belief. This negation can be understood in two ways. First, it can be taken in a weak 
sense, in which the prefix ' $u n$ ' is privative: Unglaube would designate a state of not believing or of a suppression of belief, a state that would end up in a simple lack of belief. Secondly, it can have a strong sense, in which Unglaube is not a privation of a belief, but the very act of a 'rejection' that abolishes the belief, in order to give rise to something that is more than or different from a simple suppression. ${ }^{4}$

Just as the Un-bewusst, the unconscious, opens out onto an 'Other scene' and designates much more than the absence of consciousness, as Unmensch designates much more than the nonhuman, or Un-heimlich much more than the unfamiliar, so also 'Un-Glaube' in the sense in which we are interested in it, designates much more than a lack of belief. 5

According to the immediate context, the Standard Edition sometimes translates this term by 'disbelief' or by 'incredulity', or even by a term deriving from 'unbelief': 'unbeliever'. The expression 'Unglaubensgenosse' isrenderedspecifically as 'fellow-unbeliever'. ${ }^{6}$ In the French translation of

At various moments in his writing, Freud uses different terms to describe the quality of 'rejection' as applied to Glaube or 'belief'. He uses both Versagung (translated by 'withholding,' Freud, 1896a, p.226) and sometimes Ablehnung (refusal, reprobation). We shall see that the exact nature of this 'rejection' is quite significant, for it will permit us to distinguish among a variety of modalities of 'disbelief.' when he classifies Heine's expression 'Mein Unglaubensgenosse Spinoza [my fellow-unbeliever Spinoza]' as a joke due to the use of the privative prefix ' $u n-$ ' (Freud, 1905, p.77). p.50). 
Freud's complete works, the words 'incroyance' and 'incrédulité' alternate with each other, without corresponding exactly to the choices made in the Standard Edition. Although the various options for translation can be debated according to their theoretical context, it is probable that these variations, which are, to a certain extent, justified, have helped to make Freud's notion seem more obscure, hidden and furtive than it already was.

Finally, we shall point out that philosophically, Unglaube inherits the ambiguity of the German notion of Glaube, which has two overlapping meanings, which are distinguished in English by 'faith' and 'belief', and in French by 'foi' and 'croyance'. In German, belief, Glaube, designates both the assent to all kinds of representations or propositional contents and the adherence to religious dogma (Cassin, 2004). It is impossible to use two different words to distinguish the fact of believing in God from that of believing that the sea is blue. In each case, what is in question is Glaube. It is well known that the availability of only a single term created difficulties for Luther, who tended to establish a differentiation by distinguishing between 'Glaube', in the sense of faith, and the various ways of 'believing', glauben. The German translators of David Hume also had difficulties when they had to find different terms in order to convey the distinction between the considerations on belief, in section $\mathrm{V}$ of An Essay Concerning Human Understanding and those in section $\mathrm{X}$ concerning faith.

If this lack of distinction is a potential source of conceptual confusion in German, it must be noted that the German word contains a wealth of meaning that is possessed by neither the various French nor English terms: 
what is common in the various ways of 'believing' - to give one's assent or to adhere to any content whatsoever - is emphasised by the impossibility of making a linguistic distinction.

In this article, we shall see that Unglaube also contains this ambiguity, for some of its meanings fall within the field of belief while others within that of faith. Rather than seeing this as a defect, we shall consider this vagueness to be constitutive of the notion itself and to open up a very particular field of reflection, which will enable the two senses to become meshed.

\section{Paranoic Disbelief}

In 1896, Freud started to write about the problematic of belief in paranoic and obsessional neurotic psychopathology, proceeding negatively by exploring ways in which belief is rejected: in other words, in terms of the notion of Unglaube.

Until this moment, Freud had only made metapsychological use of Glaube, belief, and had done so in the epistemological context of a psychological theory of the nature of judgement. From the context, it would seem to be a matter of the psychological domain of belief as opposed to faith. In the 'Project for a Scientific Psychology', written in 1895 and addressed to Fliess, he makes belief function with other logical operators, so as to conceptualise the general functioning of the psychic apparatus. In this theoretical framework, belief is a function of the ego: distinguishable from, yet always correlated with the perceptual system. This enables Freud to account for two different modes of knowledge: subjective knowledge (founded on the 
formation and arrangement of representations) and objective knowledge (established on the construction of perceptions). Thus, for a perception to be considered effective (i.e., distinct from a representation), the indication of reality' is necessary and leads to belief, which is defined as a 'judgement of reality' (Freud, 1895, p.333). In contrast, representation involves postponing belief.

There does exist a non-pathological exception to this process: the dream. In the latter, belief is sought and participates not in the distinction between, but rather in the confounding of representation and perception: in this case, it applies to representation, to which it thereby gives the characteristic of a perception. This is why Freud states that 'dream ideas are of a hallucinatory kind; they awaken consciousness and meet with belief' (Freud, 1895, p.339).

Freud first presents the concept of Unglaube as a mechanism in psychopathology in his letter to Fliess of 30 May 1896.

In paranoia, he writes, 'defence is manifested in disbelief (Unglauben)' (Freud, 1896b, p.231). What precisely does this mean? In what way is the constitutive mechanism of paranoia based on a 'refusal to believe'? What exactly is being refused?

This position is even more surprising since the clinical picture of paranoia in particular its delirious constructions - would seem, rather, to suggest an excess of belief. Yet Freud says the opposite: paranoia is grounded in a modality of rejection of the process of belief, a modality that he designates as 'disbelief'. 
To grasp his meaning, it is crucial to think of disbelief not as a phenomenon or a symptom but rather as a process, and, indeed, an unconscious process. Thus, what is to be examined is not the phenomenology of delusion and the sort of belief that it commonly implies in the patient's consciousness, but instead the unconscious logic that organises paranoic structure and which Freud relates to disbelief.

To form a clearer idea of what is not believed, it is useful to take the scenic route through several of Freud's other texts of the period, especially The Neuroses of Defence' (1896a) and 'Further Remarks on the Neuro-Psychoses of Defence' (1896c), which provide the necessary context for understanding his letter of 30 May.

In these texts, Freud develops an illuminating conception of the origin of psychic functioning in general, and not only from the point of view of psychopathology. His originality lies in relating the question of the constitution of the psyche to the subject's encounter with the sexuality. ${ }^{7}$

We shall specify, out of a concern for rigour, that in 1896, Freud was still using the model of the 'neurotica'8: sexual scenes that had really taken place. It was during the following year (Freud, 1985, Letter 69 of 21 September 1897, p.264-66) that he gave up this paradigm in order to introduce that of the phantasy. In our reading of the text of 1896 , we can therefore anticipate the correction that he would himself make in his distinguished from other psychological theories. 
metapsychological presuppositions. Thus we shall understand the trauma of sexuality not in terms of a situation - a traumatic scene that was really experienced by the child - but of a structure: for every subject, the emergence of sexuality includes a dimension that creates a trauma.

According to the conception of 1896 (which would be more or less masked by Freud's later metapsychological advances), the subject's first encounter with sexual reality breaks open the barrier of the pleasure principle and is experienced most often as unpleasure (Unlust). Depending on the case, this affect of unpleasure can undergo various vicissitudes: it can be transformed into anxiety (the anxiety, for example, that results from little Hans' first erections), into disgust (which, according to Freud, is the characteristic affect of hysteria) or it can take the form of a pleasure that is too intense and which is not repressed (this is the case with the Rat Man, when the young boy caresses his governess' sexual organs). Although it is not itself a representation, the initial traumatic and inevitable appearance of a 'sexual excess $^{9}$ (Sexualüberschuss) always turns out to be represented by the sort of 'reproach' that Freud calls 'primary self-reproach' 10 (primären Vorwurf) (Freud, 1896a, p.227). In using the term, 'reproach', Freud supposes that subjects subjectivize sexuality by making themselves guilty of it; it is in this form that they turn it into a representation.

9 The Standard Edition translates this expression as 'surplus of sexuality' (Freud, 1896b, 230).

10 For a discussion of the choice made in the Standard Edition to translate the German term 'Vorwurf' exclusively as 'self-reproach' (i.e. 'Selbstvorwurf'), a choice which is not followed in French translations, see footnote 2, p. 220 (Freud, 1896a). 
This representation is rejected (and we shall examine the differential character of this rejection), Freud therefore remarks that 'a repression cannot be explained' without this 'premature sexual stimulation' (Freud, 1896a, p. 221). Repression thus becomes a defence against a 'premature' incursion of sexuality, which exceeds the subject's capacities of elaboration by breaking through the pleasure principle. All the psychoneuroses are constituted as psychoneuroses of defence against the unbearable (unverträglich ) or incompatible (unerträglich) ${ }^{11}$ character (Freud, 1894, p.51) of a 'high-tension' sexual reality, which the primary reproach comes to mark. The quality of the defence is what separates the different types of psychoneurosis.

What can be said specifically about paranoia? Freud is categorical: in it, 'belief (Glaube) has been withheld (versagt) from a self-reproach' (Freud, 1896a, p.226). Five months later, in his letter to Fliess of 30 May 1896, he observes that paranoic defence is manifested in disbelief (Unglaube). For Freud, therefore, paranoic subjects refuse to admit - in the sense of what Freud, in 1925, in his article, 'Negation', will call a Bejahung - the primary reproach that represents the inaugural sexual reality with which they do, however, have to deal. The 'Bejahung', literally 'affirmation', designates, literal meaning is 'unbearable'. A note in the Standard Edition indicates that 'unerträglich' is rendered in this way because of a possible misprint in the German text. Instead of 'unerträglich', we should read 'unverträglich'. In further support of this reading (which is not discussed in the French translations), we note that Freud himself translated the term into French as 'inconciliable', that is, 'incompatible' (see Freud, 1894, footnote 4, p. 51). 
according to Freud, the mythic first moment of the constitution of the psychic apparatus, in which the subject takes what is good into itself. Freud names 'Ausstossung' the symmetrical movement of expelling what is bad. In conformity with what Freud had already emphasised in 1894, the paranoic subject 'rejects (verwift) the incompatible (sic) idea together with its affect' (Freud, 1894) and behaves as if neither had ever existed.

Consequently, the refusal (Versagung) to believe in the reproach, a refusal that founds paranoic disbelief, and which Freud identifies in 1896, is analogous to the rejection (Verwerfung) of both the representation and its affect, which Freud had emphasised in 1894. The difference between these two moments is that in 1896 , Freud introduces the term, 'disbelief', probably because he had, in the meantime, referred to belief in the 'Project for a Scientific Psychology'.

This process of paranoic disbelief involves precise clinical consequences. The refusal to believe in the primary reproach, and correlatively, in the 'premature sexual stimulation' that it represents does not make either of these terms disappear. On the contrary, the reproach (the representation) and its sexual reality (its affect) are 'projected', and not repressed, onto the other or the counterpart, who then becomes the support and the agent of this reproach and of the unbearable sexual arousal that is correlated with it. We can understand then why Freud claims that the 'primary symptom' (Freud, 1896a, p.226) (primären symptom) of paranoia - the one that characterises its style most fully - is a distrust of others (Freud, 1896a, p.226). For the other, indeed, becomes the person who issues the primary 
reproach, which appears in its pure form and 'returns from without' (von außen wiederkehrt) (Freud, 1911, p.71). This is the classic form of the insult in the verbal hallucination: 'Luder!' ('bastard', even 'slut'), shout the voices that persecute Schreber, when they are not even more sardonic in continually repeating, 'The deuce of a fellow!' In addition, the counterpart, in serving as the support of the 'sexual excess', incarnates the will to a persecutory jouissance; this is the limitless concupiscence of Schreber's god or the 'influencing machine' that excites Tausk's patient's genital organs by long distance (1933). The subjective effects of disbelief are therefore mistrust and certitude, which respectively mark a modality of the social bond and a cognitive type, both of which are specific to paranoia. These clinical effects also concern analytic treatment. Freud, long after his writings of 1896, in his article, 'Some Neurotic Mechanisms in Jealousy, Paranoia and Homosexuality' (1922), would point out the clinical consequences of paranoic disbelief, even if, in this case, he focuses on the quality of the transference. Recounting the dream of a paranoic patient, a dream that he calls 'very characteristic', he writes:

He saw me shaving in front of him, and from the scent he realized that I was using the same soap as his father had used. I was doing this in order to oblige him to make a fathertransference on to me (Freud, 1922, p.229).

Then he comments:

The choice of this incident for his dream quite unmistakably betrays the patient's depreciatory attitude to his paranoic phantasies and his disbelief (Unglaube) in them (ibid.). 
Incidentally, the English translation, 'disbelief' is more coherent than the term used in the French translation of the complete works, which prefers, in this case, the term 'incrédulité', thus obscuring the genealogy of Unglaube. Freud emphasises here that this disbelief throws a shadow of mistrust (the primary symptom) which appears in the dream through the impression of forcing that the patient feels and imputes to Freud, since he identifies him with a paternal figure. Freud writes that, according to the patient, 'I was doing this in order to oblige him to make a father-transference on to me'. ${ }^{12}$ On the basis of the dream elements that seem incongruous with reality (for example, Freud notes that he did not need to use shaving soap at all because he wore a beard) a neurotic patient would have been able to extract an unconscious wish from this dream: love for the Father conveyed by transference-love. Yet Freud emphasises pertinently that the paranoic patient does not believe, in the radical sense of Unglaube, in his own imaginative productions. The result of this refusal to believe is a mistrust that is linked to the feeling that this transference is being constrained and is coming 'from without'; it derives not from the subject but from the other. It is hardly astonishing that, in this clinical example, disbelief is directed towards paranoic phantasies and has consequences in the transference. However, it remains a matter of the same process of unbelief. Indeed, if the paranoic refusal of belief always targets the self-reproach incurred in premature sexual stimulation - thereupon prohibiting the subject from feeling guilty about and responsible for it (unlike in obsessional neurosis, see below) - this also closes off the possibility of an eventual acknowledgement of subjective 
involvement in the phantasies (and an acceptance of the desire which they harbour). For this subject, the phantasies will be experienced as foreign (imposed 'from without') and threatening, and may contribute to the construction of a delusion. In this example, Freud does not only represent a malevolent paternal figure in the transference. He also incarnates, beyond the phantasy, the very sexual excess the patient cannot acknowledge, and which he can only experience as a forcing and a threat that comes to him from someone else (in his case, Freud). One can understand how paranoic disbelief can serve as the origin of the mistrust that colours certain negative transferences in the analytic treatment of psychotics.

If we return to the more general question of paranoic disbelief and its place in Freud's work, it seems that Unglaube has not met the fate that could have been expected in terms of its decisive importance for understanding the mechanism of paranoia. One can wonder why, in the article on the Schreber case in 1911, which is entirely devoted to paranoic psychosis, 'disbelief' or even 'belief' does not even appear once, although, as we have just seen, Freud refers to this process again in 1922. How is it possible to explain the covering-over of such a notion in a text that is as crucial as the study of Schreber? ${ }^{13}$ In doing so, did Freud finally choose to avoid using the term Schreber case in 1911, Freud attempted to ascribe 'belief' to the processes of perception and representation. In two 1907 letters to Jung, he takes the additional step of bringing in the concept of libido (Freud, 1974, Letter 20F, April 14,1907, p.32-35 and Letter 23F, April 21, 1907, p. 40-43). However he does not refer to 'disbelief' because it is not an issue of the rejection of belief. 
'belief' or 'disbelief,' since he wanted to locate psychoanalysis within the field of the natural sciences (Naturwissenschaften)?

We find this question important, but also quite difficult to answer. We would like to note that although Freud changes terms, or rather, privileges that of projection in 1911, the process that he expounds has undergone no major conceptual modification. In 1896, he had, indeed, already connected the mechanism of projection with the process of disbelief in paranoia, by emphasising that the vicissitude of the reproach was to be projected.

Two points still need to be added in this connection: first, while the term, 'pro-jection' - which means, etymologically, 'throw forward', insists on the movement of expelling something to the outside, 'disbelief' emphasises the movement of refusal. The common point between projection and disbelief is the process of re-jection.

Second, the 'projection' that appears in psychosis, and which Freud describes in 1911 in the Schreber case, is atypical, and may well deserve another name. This is probably why Freud does not name it as such and specifies the difference, at the end of his text on Schreber (Freud, 1911, p.71), between neurosis and paranoia: in the former, what is usually 'suppressed internally'14 will afterwards be 'projected outwards'15 (our italics), whereas in paranoia, what is 'abolished internally' 16 will 'retur[n] from 'die innerlich unterdrückte Empfindung' 
without'. ${ }^{17}$ In this way, it is implicitly the singularity of paranoic disbelief as a psychotic mechanism that Freud is trying to conceptualise; this mechanism functions in terms neither of the classic mode of repression nor of the type of projection that is found in neurosis ${ }^{18}$. Instead, the process that includes the 'abolition' of a content that is fated to 'return from without' is not linear and implies a complex, aspherical ${ }^{19}$ psychic space, which cannot be reduced to a simple intuitive opposition between inside and outside. Such a logic makes the paranoic Unglaube into something that is much more than a simple non-belief, one that would be established by the refusal of a representation that would then be projected onto the outside. The abolition of belief in a representation implies, for the paranoic, that the content that returns from without is not believed and presents no dialectical flexibility, as

Lacan would elaborate this singular topology of rejection in psychosis in his third seminar, The Psychoses. This enabled him, the following year, to forge the concept of the foreclosure of the Name-of-theFather' in his article, 'On a Question Preliminary to any Possible Treatment of Psychosis' published in the Ecrits. This concept designates the process on which psychotic logic is based. Because a full development of this concept is beyond the scope of this paper, we will just note here that the legal term that Lacan chose in order to designate the specificity of rejection in psychosis, 'foreclosure,' implies the idea of a closed space. This is reminiscent of Freud's intuition of the existence in psychosis of a radical exterior that is closed to the subject, an exterior from which a representation returns to the subject as foreign, 'from without,' such as in the hallucination. It is because this hallucination is foreclosed (and not only projected) for the subject that it appears fundamentally enigmatic to him or her.

This adjective comes from the field of optics and designates a curved, nonspherical surface. Whereas a spherical space distinguishes an interior space from the exterior, inside and outside are continuous in a complex and nonempirical psychic space (in itself, irreducible to the psychoses). It is, in this sense, aspherical and involves the subversion of spatial opposition. Aspherical space concerns those topological figures whose surface is "unilateral," such as the Möbius strip. 
would be the case of a representation or an ordinary perception. What is rejected from the field of belief imposes itself with certitude on the subject.

It also now seems relevant to return to Freud's texts from 1896 mentioned above in order to distinguish paranoic disbelief from another modality of rejecting belief, and thus to establish a differential Freudian clinic of paranoic psychosis and obsessional neurosis.

\section{Obsessional Incredulity}

The obsessional also testifies to a 'refusal to believe'. We shall prefer, however, in this case, to use the term 'incredulity' rather than that of 'disbelief'.

In the obsessional, the Unglaube is not 'primary', as it is in paranoia, but ‘secondary'.

If, in paranoia, 'the subject withdraws his acknowledgement of the selfreproach' (Freud, 1896c, p.184) and therefore refuses to believe in the first reproach and in its sexual reality, the obsessional subject, on the other hand, believes in it. Whereas the paranoic begins by not believing, the obsessional begins by believing. Thus, in obsessional neurosis, as Freud declares, 'the self-reproach is acknowledged as justified' (Freud, 1896c, p.184). What does this mean?

This 'acknowledgement' of the reproach constitutes a sort of prefiguration of what we defined above, following Freud (1925), as the Bejahung: the obsessional 'admits' the encounter with sexual reality; it is not rejected, as it is in the paranoic. Fundamentally, the obsessional is a 'believer', but a 
'believer' who turns out to be... incredulous. Only later will he begin to doubt, to be point of falling ill from this activity. Let us remember, in this connection, that this tendency led Falret 20 to call obsessional neurosis the 'madness of doubts'.

How is this incredulity formed? Freud explains that the first operation of 'acknowledgement' is followed, in a second logical moment, by repression, and then by the return of the repressed, which leads to the formation of the 'primary symptom': not, in this case, mistrust, but 'conscientiousness' (Freud, 1896a, p.223). This is the clinical example that Freud gives, presumably because he considers it paradigmatic for this neurosis: the subject behaves so as to be 'irreproachable' and spares no effort to be so, throwing himself into operations of incessant verification. According to Freud, this reaction-formation constitutes the 'response' to the unconscious reproach that the subject addresses to himself, without his knowledge, because he has committed a fault concerning sexuality. In this respect, the formation of scrupulousness is a solution that attempts to counter guilt.

Then, in obsessional neurosis, a second, conscious reproach arises, which aims precisely at this primary symptom, scrupulousness. Having no access to the motives for his guilt, which the various rituals and verifications fail to appease, the obsessional looks for reasons for it and comes to reproach

20 Jean-Pierre Falret (1794-1870) was a French alienist who occupied an essential place in the history of classical French psychiatry and seems to have been the first person to use the expression 'madness of doubts'. His son, Jules Falret (1824-1902), who was also an alienist, officially used the expression during a discussion of the Societé MédicoPsychologique in Paris in 1866, in reference to his father. It seems, nevertheless, that the expression was handed down to posterity in 1875 by the work of the French psychiatrist, Henri Legrand du Saulle (1830-1886). 
himself not for a sexual fault (to which he has no access because of repression), but for not being sufficiently... scrupulous. Ignorant of the movements that animate him, he blames himself for any 'failures' of his habitual and insistent irreproachability.

Obsessional incredulity bears precisely on this second reproach. The subject reproaches himself for not being scrupulous enough..., yet he also knows that he is, and therefore he does not believe this reproach. As Freud claims:

...the conscientiousness which the subject has acquired during his healthy interval now protects him from giving credence [Glauben zu schenken] to the self-reproaches which return in the form of obsessional ideas (Freud, 1896c, p.184) (our italics).

Thus, the obsessional neurotic does not completely credit the secondary reproach, and doubts its legitimacy. The reproach, far from being apprehended with certitude (as is the case in paranoics, who do not doubt the reproaches that return from without), is, in the obsessional, the opposite of unshakeable. This point of incredulity manifests itself in the 'colour' of the verifications that are a part of obsessional rituals, verifications that are as irrepressible as they are empty, from the beginning, of any true adhesion on the subject's part; for example, the subject knows that he has scrupulously turned off the gas, but reproaches himself for not being scrupulous enough, and therefore makes an effort at verification that he cannot prevent... although he knows that it is absurd. Incredulous about the reproach that he has not been scrupulous, he doubts that his own verification is wellfounded, but he is so superstitious that he cannot prevent himself from performing the ritual that his guilt dictates to him. He resembles someone 
who, although he does not really believe that bread placed upside down on the table brings bad luck, cannot prevent himself from setting it right side up. Paradoxically, the ritual is repeated so often that it ends up being emptied of any true adhesion on the part of the person who is so 'scrupulously' alienating himself in it. In a sense, the obsessional is a pious person who no longer believes in his own religion.

From a metapsychological point of view, the second reproach (not being scrupulous enough) can be said to represent the first (having committed a sexual fault), but the subject refuses to believe in the second, for he believes, in fact, only in the first reproach. Unconsciously, the obsessional truly believes that he is guilty of a sexual fault. For that reason, he also cannot really believe consciously that his guilt results from his lack of scrupulousness. He foresees, as it were, that the second, conscious reproach is only an imitation of another, unconscious and more authentic reproach. Yet this contradiction, far from enabling him to get his bearings, encloses him within a logic of doubt in which he gets lost and from which it is impossible to exit, because he does not recognise its true determinants.

The obsessional refusal of belief is very particular and relative, in contrast to the paranoic's radical rejection of belief. Obsessional incredulity has the character of a negation (Verneinung). Just as the claim 'it's not my mother' contains a negation that allows the repressed content to be unveiled (Freud, 1925, p.236), so also, in this case, the doubt about the secondary reproach allows him to glimpse the primary reproach that is, in fact, the support for the representation of sexual reality. The belief is actual, and is not purely 
rejected, as it is in paranoia. To truly understand this process, it is useful to think of it in negative terms: the obsessional's incredulity is in fact the negation of his real belief. In other words, for the obsessional, Unglaube is secondary to the more primary belief in the reproach.

The representative character of the reproach has been displaced: it has neither been 'projected' nor 'abolished'. The current reproach, which usually concerns an insignificant situation and in which the subjects do not believe, secretly re-presents another reproach in which they do 'believe', although they have no access to it, for it refers to sexual reality and therefore remains unconscious and repressed. For example, the nineteen-year-old woman whose case Freud mentions in the Introductory Lectures on Psycho-Analysis (Freud, 1916) is afraid that she is never scrupulous enough - and reproaches herself for this - in her ceremony of going to bed, a ceremony that has become an obsessional ritual, in which she protects herself against any external sounds that could awaken her during the night. She knows, however, that this reproach is absurd. Freud, nevertheless, demonstrates that it remains vigorous because it represents another - unconscious reproach, which is linked to the sexual desire that underlies her erotic dreams and troubles her sleep. The type of 'rejection of belief' implied in obsessional incredulity is motivated by repression.

We might supposethat this close relation between repression and neurotic incredulity contradictsFreud's proposals in 'Draft N' in the chapter fittingly entitled 'Transposition (versetzung) of Belief': 'Belief (and doubt) is a phenomenon that belongs wholly to the system of the ego (the Cs.) and has 
no counterpart in the Ucs. In the neuroses, belief is displaced (verschoben); it is refused to the repressed material if it forces its way to reproduction and as a punishment, one might say - transposed on to the defending material' (Freud, 1897, p.255-6). An overly hasty reading of the passage might lead us to conclude that belief is not repressed, that it belongs to the Pcs/Cs system and that it is transferred to either the register of the defences or to the primary symptom (scrupulousness) and the secondary reproach; such a reading would be the exact opposite of what we have been arguing in reference to neurosis. However, the nuance to be understood here is that what Freud calls 'belief' in 'Draft $N$ ' is not the kind of primordial admission that he designates with the same term in 'Draft $\mathrm{K}$ ' and in 'Further Remarks on the 'Neuro-Psychoses of Defence'. In Draft N, Freud essentially equates belief and doubt (i.e., 'Belief (and doubt)...'). Thus, here he is speaking of belief in the sense of an opinion lacking certitude, something that is probable, an estimate, a bias, and - continuing up the ladder of negative magnitude, as it were - worthy of doubt, scepticism, suspicion and incredulity. In so doing, he says exactly that, in the neuroses (as opposed to paranoia), incredulity, doubt, etc. are refused to repression. This is a double negation: in the neuroses there is precisely no doubt regarding the primary reproach, which isthe repressed element. Incredulity, doubt, etc. remain conscious and get caught up with the defences (the secondary reproach of the primary symptom), which accords with Freud's work on obsessional neurosis in 1896. 
We shall add thatthe repression that operates here, as Freud points out in the case of the Rat Man, 'makes use of another, and in reality a simpler mechanism' - simpler in relation to repression in hysteria (Freud, 1909, p.195). What is in question is a mechanism of displacement (Verschiebung), the displacement of a primary by a secondary reproach, which operates 'by a severance of causal connections brought about by a withdrawal of affects' (Freud, 1909, p.231). This disjunction by displacement makes the true cause of the secondary reproach unrecognisable. This is why the obsessional subject refuses to believe in it and finds his own ritual absurd. Nevertheless, this belief in the primary reproach and its sexual reality lends the character of constraint (Zwang) to the secondary reproach that represents it. In addition, it is striking that obsessional incredulity gives this neurosis its style: distrust (as opposed to mistrust, as in paranoia) even doubt about situations and things that are the most certain and the best established.

Be that as it may, obsessional incredulity is a modality of Freud's Unglaube that shows how subjective positions (here, paranoic psychosis and obsessional neurosis) differ fundamentally in their subjective and unconscious treatment of belief. Whereas belief (in the representation of the subject's first encounter with sexual reality) is radically refused in psychosis, it is repressed in neurosis and appears in its negative form, incredulity. In short, in obsessional neurosis, belief and incredulity are the obverse and the reverse of the same surface.

In an article entitled 'Belief, Disbelief and Conviction' (Ferenczi, 1980, [1913]), Ferenczi gives a fine description of various situations in which belief 
and incredulity are not mutually exclusive. He claims, in particular, that blind incredulity about one doctrine is like the verso of a coin, the recto of which is a blind belief in another. Stating that psychoanalysis permits one to pierce through the mystery of a mechanism that (falsely) seems to be contradictory, he brings in obsessional neurosis as an example in which primitive trust is repressed such that only its negative version - scepticism remains apparent. This remark, which Ferenczi applies particularly to the beginning of the analytic treatment of obsessional subjects, ties up with Freud's approach to incredulity, as a specific modality of disbelief in obsessional neurosis. Incidentally, Ferenczi uses the term, Unglaube, which the English translators chose to translate as 'disbelief', whereas our suggested translation by 'incredulity' helps the reader understandmore distinctly the difference between a radical rejection of belief (in paranoia) and a much more relative rejection of it (in obsessional neurosis).

Without being satisfied with this binary division between paranoic disbelief and obsessional incredulity, we can now envision, with Freud, another modality in which belief is treated negatively - another figure of disbelief which differs from paranoia while being franker than obsessional incredulity. In short, whereas paranoic disbelief is primary and obsessional incredulity secondary, we shall now examine a third, dialectical modality of disbelief.

\section{Act of Disbelief and Subjective Transformation}

We shall point out first that the third modality of disbelief that can be extracted from Freud's use of Unglaube is, unlike the first two, neither organised without the subject's awareness nor attached to a particular 
subjective position, such as paranoia and obsessional neurosis. On the contrary, the Unglaube that we are now going to discuss leads to a transformation of subjects' relations to their own beliefs, and thereby supposes the possibility of a change in their relation to them. Linked to unconscious determinations (and not the fruit of a deliberate decision), it must be understood to produce a subjective transformation.

We shall no longer ask what subjects make of the material that comes from the drive and overwhelms their capacities of psychic elaboration, as is the case in the two preceding modalities (which are located in terms of psychopathology), but shall, instead, question how their beliefs are organised, how they become rooted in unconscious knowledge, and how they can be deconstructed. In this framework, that which is believed is no longer what Freud calls the primary reproach, but rather the subjects' place in the phantasy that coordinates ideals, organises object-relations and sustains the identifications that situate them in the world. The question is not that in which' subjects believe but instead 'how' or 'the way in which' they believe (fictions, theories).

Freud uses Unglaube in this sense on three occasions, twice to refer to his own subjective transformation and the third specifically to mention that of Leonardo da Vinci as a child. We shall seek to locate what determines this disbelief, for what is at stake here is fundamental for both the epistemology and the ethics of analytic theory and practice.

The Child's Act of Disbelief 
The paradigm of this 'disbelief' is the child's 'act of disbelief', as Freud treats it in Leonardo da Vinci and a Memory of His Childhood. Each of us knows this modality of disbelief, even if we have forgotten it. It concerns the moments in which the child gives up believing in the fictions constructed by adults, stories that are, in fact, modern myths - such as those of the Tooth Fairy or Father Christmas - that circumscribe the enigmas of castration and birth.

Freud himself mentions the moment when the child relinquishes a belief in the story - which, indeed, is a bit outmoded now - of the stork who 'brings' children, a fable that was supposed to answer the child's question, 'Where do babies come from?', while veiling any reference to sexuality.

In this way we have been astonished to learn that children refuse to believe the bits of information that are given them - for example that they energetically reject the fable of the stork with its wealth of mythological meaning - that they date their intellectual independence from this act of disbelief... (Freud, 1910b, p.79, our italics).

It is uncertain whether readers of Freud have genuinely understood the power of the subject's transformation of these true 'decisions' of childhood, which Freud designated very aptly as 'act[s] of disbelief' (Akt des Unglaubens) (Freud, 1910b [GW VIII], p.146): acts that are to be understood in the strong sense, for they establish a discontinuity in children's subjective life, and do so at the children's own initiative. This 'act' of disbelief marks a fundamental and irreversible rectification in subjects' relation to the Other (here incarnated by the parents), whom they discover to be possible liars. We 
understand the term 'Other' ${ }^{1}$ in the sense in which Jacques Lacan defined it (1988 [1954-1955]): as one of the possible names of the unconscious, which Freud designated as an 'Other scene' (der andere Schauplatz). To discover that another person is potentially a liar is, first of all, to take cognizance of a state in which the truth that the Other is supposed to contain beyond the lie is therefore not immediately accessible. The status of the Other changes here. For the child, it can no longer be reduced to his or her parents or to analter ego. The Other, as written with a capital ' $\mathrm{O}$,' becomes a place 'beyond all intersubjectivity' (Lacan, 1988 [1954-1955], p. 177). It is a 'fundamental alterity’ (Lacan, 1988 [1954-1955], p. 236), an 'essential alien’ (Lacan, 1988 [1954-1955], p. 177). The process of transformation of the relation with the Other has a reciprocal consequence on the statuses of both the Other and the subject. If the Other can lie, then so can the child, and not only to another person but also to him- or herself. From this point forward, the subject is no longer transparent to itself. There is, within and beyond as well, an unknown, Other part, which, however, is determinant. Now, the supposition of this opacity in the suject is not unrelated to the hypothesis of the unconscious, which Lacan defines as the 'place of the Other' and which is that of the truth of the subject, a truth that is intimate and yet unknown.

Not only is it a cognitive skill to be able to acknowledge the possibility that the Other (the one who incarnates it, in this case, the parents for the child) his English translators have generally preferred 'the Other' (Lacan, 1966-67, 25 th January 1967 Session). 
can lie, ${ }^{22}$ but the subject also considers that the Other itself needs fictions (such as the fable of Father Christmas, etc.) in order to gain a clearer understanding of the enigma of castration to which it is itself submitted. With this realisation, children conclude that the Other is submitted to the same law as they are, and the hypothesis of its omnipotence is deconstructed. When children, for example, become aware that Father Christmas does not exist, the parents whom they have credited with knowledge fall from their pedestal. What falls in this operation of Unglaube is not only the content of a belief but also what or who has served to guarantee this belief. It could also be noted that this belief is not unrelated to the fiction that sustains the dynamic of transference in analytic treatment ${ }^{23}$.

Having located a function of this sort in the young Leonardo concerning the fable of the stork, Freud correctly emphasises that this act of disbelief inaugurates a new relation to knowledge for the child, by reviving his 'desire to know' (a desire to which Freud attributes the origin of Leonardo da Vinci's future as a researcher). On the basis of this logical time, the child will then proceed to interpret for himself the enigma of castration and desire by forging his own fictions (infantile sexual theories and the family romance) without contenting himself passively with those provided by adults.

If this childhood ordeal constitutes the paradigm of this act of disbelief and the subjective transformation that is its effect, this modality of disbelief can

22 This skill has intrigued logicians such as Turing (1950) and analytic philosophers (see treatments of the theme of self-deception). See 'Act of Disbelief and Transference' below. 
also be applied to other fields. Freud gives us two examples from his own experience, which are linked to the growth of his relation to psychoanalysis. These examples will allow us to deal, first of all, with the epistemological range of Unglaube and its role in his theoretical elaboration, and then with its impact on the ethics of the treatment, since the process of disbelief will provide us with a way of conceiving, in part, the dynamics of a treatment.

The Act of Disbelief in the Development of the Theory

Freud's famous letter to Fliess of 21 September 1897 (Freud, 1985, p. 264266), in which he announces that he has given up on his 'neurotica' must, as we shall argue, be considered as Freud's act of disbelief. The term 'Unglaube' (which the Standard Edition translates correctly as 'disbelief') is present here to designate the moment when Freud ceases to believe in the systematic factual reality of his hysterical patients' allegations. Let us recall that this theoretical decision constitutes a decisive turning point for analytic theory: until that moment, Freud had taken what his patients said at face value and did not wonder whether the traumatic scenes described to him had a phantasmatic dimension, concluding thereby that such scenes could explain hysterical suffering. In 1897, he suddenly becomes aware that he has been mistaken on this subject, and 'no longer believes it'. Here is what he writes to Fliess, the man whom he would call his 'only audience' (Freud, 1985,Letter of 19 September 1901, p.450):

And now I want to confide in you immediately the great secret that has been slowly dawning on me in the last few months. I no longer believe in my neurotica [theory of neuroses]... So I 
will begin historically [and tell you] where the reasons for disbelief came from (Freud, 1985, Letter of 21 September 1897, p.264) (our italics).

We would like to suggest that this disbelief should be considered as an authentic 'act' since it implies a turning point and a growth in analytic theory, and does so precisely in terms of Freud's subjective relation with psychoanalytic knowledge. This 'confession' to Wilhelm Fliess constitutes a point of no return in relation to his earliest beliefs.

In the new conception of psychoanalytic theory, this change has the following effects: the reality of the phantasy - its truth-value as a fictional structure - is, from now on, taken into account, as is the necessity for interpreting the patient's claims, which can no longer be taken literally as aetiopathogenic facts.

This deconstruction of belief has a profound impact: it involves a subjective disruption and makes a new field of discovery possible. Going beyond the belief in the hypothesis of a real early seduction leads Freud, first of all, to a logical limit, a point that is intrinsically undecidable in analytic theory: 'one cannot distinguish between truth and fiction that is cathected with affect' (our italics)(Freud, 1985, Letter of 21 September 1897, p.260). The 'material reality' of the seduction scene is simultaneously indemonstrable and irrefutable.

This act of disbelief does not leave the researcher's subjectivity untouched:

When this aetiology broke down under the weight of its own improbability and contradiction... the result at first was helpless bewilderment... the firm ground of reality was gone (Freud, 1914, p.17). 
So it was up to Freud to take heed of his resolute desire and to follow through with his explorations of the consequences of his discovery.

At that time I would gladly have given up the whole work, just as my esteemed predecessor, Breuer, had done when he made his unwelcomed discovery. Perhaps I persevered only because I no longer had any choice and could not then begin again at something else. At last came the reflection that, after all, one had no right to despair because one has been deceived in one's expectations; one must revise those expectations... And now, from behind the phantasies, the whole range of a child's sexual life came to light (Freud, 1914, p.17).

Here we see the discovery of the breadth of the child's sexual life, a discovery permitted by Freud's act of disbelief, which is consubstantial with a transformation of his relation to knowledge. Knowledge is to be understood here in the double sense of unconscious knowledge - which is specific to Freud's subjective reality - and the knowledge of psychoanalysis, since a transformation of analytic theory was now called for: it was necessary to reinvent the theory (and with it the clinic and the practice) in order to give a specific rationality to this discovery.

This act of disbelief follows a logic that is the opposite of paranoic disbelief. In one case, the sexual reality of representation is unveiled; in the other, it is rejected.

\section{Act of Disbelief and Transference}

Freud also relates another of his experiences that involves an act of disbelief and which had an impact on psychoanalytic theory. This is the famous disturbance of memory that destabilised both his sense of reality and his 
identity (Harrison, 1966) ${ }^{24}$ while he was visiting the Acropolis in 1904, and which he reported in his open letter to the French writer, Romain Rolland in 1936. Here again, Unglaube is mentioned, this time to characterise the disturbance of memory. This term, indeed, figured in the original title, which was later modified. ${ }^{25}$ The translators of the Standard Edition chose to render this word sometimes as 'incredulity' and sometimes as 'disbelief', whereas our suggested translation helps the reader understand thatthe process that Freud was discussing arises from an authentic act of disbelief during which theway in which he had believed until then collapses.

Let us recall what is in question in this 'disbelief'. As soon as he arrives in Athens during his improvised Greek holiday with his younger brother, he goes to the Acropolis and 'cast[ing] [his] eyes around upon the landscape', finds that a 'surprising' (merkwürdig) thought comes into his mind : 'So all this really does exist' (Freud, 1936, p. 241)

Relating the trouble that grasps him to the sudden appearance of this idea, Freud qualifies this phenomenon as singular and unusual. What is being described here is very much a process of Unglaube that supposes a rejection of belief in the actual reality of the Acropolis, a disbelief that Freud expresses in the following way: 'By the evidence of my senses I am now standing on the accompanied by depersonalisation. 
Acropolis, but I cannot believe it' (Freud 1936, p.243, our italics). 'What I see here is not real (nicht wirklich)', he exclaims to himself.

This remark is preceded by another statement: 'So all this really does exist, just as we learnt at school!' The remark that the Acropolis is actually not real signals the suspension of a form of knowledge that has always been taken as established: the knowledge transmitted by schools. The subjective malaise that is associated with a transformation of the subject's relation to reality, and which is characteristic of an act of disbelief, cannot be reduced to a simple moment of incredulity, in the common sense of the term. We shall suggest, on the contrary, that this event, which never ceased to haunt Freud, can be read as a theoretical turning point that is linked to a transformation of his transferential relation with Fliess, a point that can teach us about the intertwining, in theoretical production as well as in clinical experience, of belief and transference.

What are the unconscious reasons for this disbelief? To answer this question, we do not think that it is necessary to refer to the parental imagos, and especially the maternal imago (Slochower, 1970). It is, instead, in his letter to Jung from 16 April 1909 (Freud, 1974, p.218-220) that Freud gives an important indication of what determined his disbelief in Athens. For Freud, there is an unconscious link, a 'secret influence' (geheimer Einfluß), between the publication of his Traumdeutung (which corresponds, for him, to the sense of having reached a limit), the deterioration of his profound relation with Fliess and his disbelief at the Acropolis. 
We know that only a few weeks before Freud climbed the Acropolis at the end of August and the beginning of September 1904, Fliess had accused him of having taken part in the affair of double plagiarism involving Otto Weininger and Hermann Swoboda (Porge, 1994) and that Freud had answered him, some time in July 1904, with a letter that broke off their relations. Let us emphasise, in passing, that this was not just any accusation, but was precisely one of plagiarism; it concerned the status of knowledge and of the person who is supposed to guarantee its authenticity (the author). If, as we think, Freud's disbelief in the existence of the Acropolis is the subjective effect of an act of disbelief, then this act implies a transformation of his relation to knowledge. Our hypothesis is that what underlies this transformation is the end of Freud's transferential relation to Fliess. This transferential relation had been permitted by his belief - which had just ended - in a knowledge attributed to Fliess ${ }^{26}$; this transferential operation is represented, in the letter to Romain Rolland, by the way in which the schools had represented the Acropolis ('just as we learnt at school'), a representation in which Freud no longer believes.

26 In his correspondence, Freud addresses Fliess as a man of science who ensures that there is a matching scientific guarantee for the truths about the unconscious he discovers. Moreover, Freud did not hesitate to address Fliess as the recipient of his transference: '[...] I cannot do without you as the representative [Repräsentant] of the Other [Andere],' he writes in a letter on 21 September 1899 (Freud, 1985, p. 374). In this perspective, Fliess represented the 'subject-supposed-to-know' for Freud. The 'subject-supposed-to-know' (Lacan, 1981, [1964]) is Lacan's concept for that which gives logical consistency to the phenomenon of the transference. As regards the crucial role of Freud's transference to Fliess in the origin of psychoanalysis, please see Porge's excellent work Vol d'idées ? [Theft of Ideas?] (1994). 
In consequence, a new, more vertiginous relation to knowledge imposes itself on him, in the form of the production of a completely new knowledge, that of psychoanalysis, which is represented by the Traumdeutung: knowledge for which Freud must now accept sole responsibility when confronted with a wider public (no longer restricted to Fliess) and which is not guaranteed by any Other who would possess its grounds or purpose.

\section{'Unbelief' and the Ethics of Psychoanalysis}

In order to conclude this archaeology of Freud's Unglaube, we shall emphasise the importance of this final dialectical conception of the act of disbelief as a way of envisioning analytic treatment itself, from the positions of both the analyst and the analysand.

It seems possible to us to postulate that the epistemic and subjective effects of these acts of disbelief have the same structure as the course of psychoanalytic treatment. It can be illuminating to consider that a treatment necessarily implies one or even several acts of disbelief, which destabilise identifications that had, until that moment, regulated subjects' relation to the Other, thus bringing into question what they had been able to believe or even who they believed themselves to be. The process of analysis enables analysands to deconstruct the identifications and the beliefs that had, until that point, organised their relation to existence and to discover the possible emptiness of the foundations upon which such identifications rested; analysis permits them to become fully aware of the vanity of the ideal that had, until that moment, been connected with their beliefs and 
identifications. ${ }^{27}$ In other words, no guarantee exists concerning the ethical choices that analysands can make for their own lives. The experience of the treatment and its consequent reorganisation of beliefs does not lead to a disenchanted scepticism, to fatalism or to the 'sad passions'; on the contrary, it gives a place to an act that is grounded in reason because it does not rely on guarantees. This act does not occur without some effects that can be of the order of enthusiasm for the subject who has been modified by it.

Freud's work thus proposes, in our opinion, to orient us towards an ethical choice rather than to locate us through belief. If, stripped of their most certain reference points by Unglaube, subjects can be led to uncertainty and disorientation, the verso of this wavering can be a subjective transformation. Such a transformation is sustained by a renewal of the social bond in which they had been located until that moment, as well as a significant reorganisation of a number of their relations: to love, desire, the other sex, power, etc. For this reason, these acts of disbelief are the condition for the possibility of new discoveries - whether they are bearable or not - as well as for inventions, for which the subjects will have to take responsibility, and which they will have to know how to use.

To conclude, we would like to suggest that an analytic treatment, through the process of disbelief, produces unbelief, in the sense in which the result (unbelief) should be differentiated from the process (disbelief). Note that the treatment was already noticed by Freud, who opposed it to the additive dynamic of psychotherapies based on suggestion (Freud, 1910a). 
Standard Edition uses the term 'unbeliever' to translate an expression to which we have already referred: Unglaubensgenosse. This is how Heine designated Spinoza, ${ }^{28}$ whose formula 'Deus sive natura' ${ }^{29}$ constitutes 'the emblem of unbelief' (the very unbelief that led him to be 'excommunicated' by the Jewish community of Amsterdam in the rare procedure of the 'herem').

The Standard Edition's felicitous translation, by relating Unglaube to 'faith', pins down a dimension of Freud's conceptualisation that had only been touched upon in his work at the time, despite its relevance to his own preoccupations. As Velmorel says:

Freud starts out from a critique of religion and attempts to put psychoanalysis in its place. But he asked himself if it will be a new illusion, and answers his own question forcefully, as if he were fighting off a doubt: 'no, our science is no illusion' (Vermorel, 2009).

Here, in our opinion, the question of the relation between psychoanalysis and religion becomes knotted to the new conception of belief, which Freudian discursivity enables us to bring out. For Freud, it is no longer simply a matter of denouncing belief, in the tradition of Ludwig Feuerbach's The Essence of Christianity: treating belief as an illusion into which human beings 'project' their own ideas, an illusion from which one can be freed by rejecting it consciously. Psychoanalysis, on the contrary, relates belief and

28 Heine referred to himself as a 'declared disciple' of Spinoza (Vermorel, 2009). two terms are equivalent. 
its effects to the subject's unconscious knowledge, which thereby enlarges the question of belief beyond the strictly religious domain.

What, then, is the psychoanalyst's religion, a question that should be understood prosaically as: 'What is the grounds of the psychoanalyst's social bond'?

If psychoanalysis enables us to deconstruct a mode of relation to the Other in order to replace it with a new type of social bond, the 'unbelievers' it produces - i.e., the psychoanalysts who have reached the terminal point of their treatment - must still find a way not simply to lament when faced with the emptiness of the heavens, an emptiness that has been revealed by the unveiling of their illusions. On the contrary, if the desire comes to them, they might, in their turn, sustain the analytic offer for others and associate their own solitude in a community of work with that of their 'fellow-unbelievers'.

Translated by John Holland 


\section{Bibliography}

Cassin B (edited by) (2004). Vocabulaire européen des philosophies

[European Vocabulary of Philosophies]. Paris: Seuil/Les dictionnaires Robert.

Foucault M (1977, [1969]). What is an author? [Qu'est-ce qu'un auteur ?]. In:Language, Counter-Memory, Practice. Bouchard DF, Simon S, translators. Ithaca, New York: Cornell University Press, p.124-127.

Ferenczi S (1980, [1913]). Belief, Disbelief and Conviction [Glaube, Unglaube und Überzeugung]. In: Further Contributions to the Theory and Technique of Psycho-Analysis, Suttie J, translator. London: Karnac Books, p. 437-449.

Freud S (1894). The Neuro-Psychoses of Defence. SE III, p.41-68 [GW I, p.57-75]

Freud S (1895). Project for a Scientific Psychology. SE I, p. 283-399.

Freud S (1896a). Draft K. The Neuroses of Defence (A Christmas Fairy Tale). SE I, p. 220-229.

Freud S (1896b). Letter 46 (May 30, 1896). SE I, p. 229-233.

Freud S (1896c). Further Remarks on the Neuro-Psychoses of Defence. SE III, p. 159-185 [GW I, p.377-404] 
Freud S (1897). Draft N Notes III (May 31, 1897). SE I, p. 254-257.

Freud S (1905). Jokes and their Relation to the Unconscious. SE VIII [GW VI]

Freud S (1909). Notes upon a Case of Obsessional Neurosis. SE X p. 151318 [GW VI p.381-466]

Freud S (1910a). Five Lectures on Psycho-Analysis. SE XI, p.3-55 [GW VIII, p.1-60]

Freud S (1910b). Leonardo Da Vinci and a Memory of his Childhood. SE XI, p.59-138 [GW VIII, p.127-213]

Freud S (1911). Psycho-Analytic Notes on an Autobiographical Account of a Case of Paranoia (Dementia Paranoides). SE XII, p. 1-82, [GW VIII, p. 239321]

Freud S (1914). On the History of the Psycho-Analytic Movement. SE XIV, p.3-66 [GW X, p.43-113]

Freud S (1916). Introductory Lectures on Psycho-Analysis. SE XV [GW XI]

Freud S (1922). Some Neurotic Mechanisms in Jealousy, Paranoia and Homosexuality. SE XVIII, p. 221-233 [GW XIII, p. 193-208] 
Freud S (1925). Negation. SE XIX, p. 235-240 [GW XIV, p.9-16]

Freud S (1927). The future of an Illusion. SE XXI, p. 1-56 [GW XIV, p.323380]

Freud S (1936). A Disturbance of Memory on the Acropolis, SE XXII, p. 239250 [GW XVI, p.250-60]

Freud S (1974). The Freud-Jung Letters: the Correspondence between Sigmund Freud and Carl Gustav Jung. Manheim R, translator. Princeton, NJ : Princeton University Press.

Freud S (1985). The Complete letters of Sigmund Freud to Wilhelm Fliess, 1887-1904. Masson JM, translator. Cambridge, Mass : Belknap Press of Harvard University Press.

Grimm J \& Grimm W (1961), Deutsches Wörterbuch [German Dictionary]. München: Deutsche Taschenbuch Verlag.

Guérin N. (2006). La notion d'incroyance en psychanalyse : origine, réhabilitation et perspective [The notion of Disbelief in psychoanalysis : origin, rehabilitation and prospect], L'Evolution psychiatrique, 71: 545-557 
Harrison I-B (1966). A reconsideration of Freud's A disturbance of memory on the Acropolis" in relation to identity disturbance. Journal of American Psychoanalytic Association, 14: 518-527

Hellebois P (1992). Sur l'incroyance [About disbelief]. Quarto, 28 :46-48.

Lacan J (2002, [1946]). Presentation on Psychical Causality. In: Ecrits. Fink B, translator. New York-London : Norton \& Company, p. 123-158.

Lacan J (2002, [1953]). The Function and Field of Speech and Language in Psychoanalysis. In: Ecrits.Fink B, translator. New York-London : Norton \& Company, p.197-268.

Lacan J (1988 [1954-1955]). The Ego in Freud's Theory and in the Technique of Psychoanalysis [Le moi dans la théorie de Freud et dans la technique de la psychanalyse]. The Seminar of Jacques Lacan. Book II. Tomaselli S, translator. New York-London : Norton \& Company.

Lacan J (1992, [1959-60]). The Ethics of Psychoanalysis [L'éthique de la psychanalyse]. The Seminar of Jacques Lacan. Book VII. Porter D, translator. New York-London : Norton \& Company.

Lacan J (1981, [1964]). The Four Fundamental Concepts of Psychoanalysis [Les quatre concepts fondamentaux de la psychanalyse]. The Seminar of 
Jacques Lacan. Book XI. Sheridan A, translator. New York-London : Norton \& Company.

Lacan J (1964-65). 19th May 1965 Session. In Problèmes cruciaux pour la psychanalyse. [Crucial Problems for Psychoanalysis]. Unpublished.

Lacan J (1966-67). 25 th January 1967 Session. In La logique du fantasme. [The logic of Fantasy]. Unpublished.

Lacan J (2007, [1969-70]). The Other Side of Psychoanalysis. The Seminar of Jacques Lacan. Book XVII [L'envers de la psychanalyse]. Grigg R, translator. New York-London : Norton \& Company.

Porge E (1994). Vol d’idées?[Theft of ideas?] Paris: Denoël.

Porge E (1996). L’incroyance de Georg Cantor. In: La théorie BaconShakespeare de G. Cantor [The disbelief of Georg Cantor. In: The BaconShakespeare theory of Georg Cantor], Clichy : GREC, p. 9-56.

Slochower H (1970). Freud's déjà vu on the Acropolis. A symbolic relic of mater nuda, Psychoanalytic Quaterly, 39 : 90-102.

Slochower H (1971). Freud's Gradiva: Mater Nuda Rediviva. A WishFulfilment of the Memory on the Acropolis, Psychoanalytic Quaterly, 10 : 646-662. 
Tausk V (1933).On the Origin of the Influencing Machine in Schizophrenia. Feigenbaum D, translator, Psychoanalytic Quarterly, 2: 519-556

Turnheim M (1992). Verwerfung, Projektion et Unglaube [Foreclosure, Projection and Unbelief], La lettre mensuelle de l'Ecole de la cause freudienne, $71: 16-18$.

Turing A-M (1950). Computing machinery and intelligence, Mind, 59: 433460

Vermorel H (2009). The Presence of Spinoza in the Exchanges between Sigmund Freud and Romain Rolland, Int J Psychoanal, 90:1235-1254.

Vermorel H, Vermorel M (1993). Sigmund Freud et Romain Rolland, Correspondance 1923-1936 [Sigmund Freud and Romain Rolland, Correspondence 1923-1936]. Paris: PUF. 